\title{
Effectiveness of the Training Program in Improving Mother Child Relationship through Play*
}

\author{
Ege AKGÜN** Binnur YEŞILIYAPRAK ***
}

\begin{abstract}
This study aims to examine the effects of the "Training Program in Improving Mother Child Relationship through Play" on the interaction between mothers and their 4-5 year old children. It is an experimental study based on the pretest, post-test, follow-up test model with experimental, placebo and control groups. The study was conducted with the voluntary participation of upper socio-economic level mothers. Data were obtained by using the Parent Child Relationship Scale, written excerpts in which mothers described the relationships between themselves and their children, and video-recordings of interviews. The meaningfulness of the difference between groups was examined by using the Kruskall Wallis H and Mann Whitney U Tests, and the meaningfulness of the difference between measurements was tested by using the Wilcoxon Test. As a result of the analyses performed in all three groups, a meaningful improvement was seen in the relationships of experimental group mothers with their children.
\end{abstract}

Keywords: Mother child relationship, mother training, preschool

\footnotetext{
* This study was composed part of the PhD Thesis called "Effectiveness of the Training Program in Improving Mother Child Relationship through Play".

${ }^{* *}$ Dr. Ankara University Faculty of Educational Sciences. Tel: 031236333 50/5106.

E-mail: eakgun@education.ankara.edu.tr

${ }^{* * *}$ Prof. Dr. Ankara University Faculty of Educational Sciences. Tel: 031236333 50 /3101.

E-mail: Binnur.Yesilyaprak@education.ankara.edu.tr
} 


\section{SUMMARY}

Purpose and Significance: The present study was conducted with the aim of identifying the effects of the Training Program in Improving Mother Child Relationship through Play on Turkish mothers.

Methods: It is an experimental study based on the pre-test, post-test, follow-up test model with experimental, placebo, and control groups. The study was conducted with the voluntary participation of upper socioeconomic level mothers. A convenience sample of 27 mothers and their children participated in the study. Of these, 10 mothers were assigned to the experimental group, eight to the placebo group and nine to the control group. The program designed for the placebo group was based on the one designed for the experimental one. Placebo group training consisted of seven sessions. Likewise, the experimental group attended a weekly 90-minute training session based on theoretical knowledge and skills for seven weeks. In the following five weeks, experimental mothers used the training they received for child-centered play which took place at home once a week for 30 minutes. The training program continued simultaneously for 12 weeks via group sessions in which mothers shared their play experiences and feedback. On the other hand, the mothers in the control group received no training throughout the experiment; they were only offered a two hour "Mother child relationships and play" training after the implementation of the follow-up tests. Data were obtained by using the Parent-Child Relationship Scale, written excerpts in which mothers described the relationships between themselves and their children, and video-recordings of interviews during which mothers evaluated the training program. The meaningfulness of the difference between groups was examined by using the Kruskall Wallis $\mathrm{H}$ and Mann Whitney U Tests, and the meaningfulness of the difference between measurements was tested by using the Wilcoxon Test.

Results: This study evaluated the effects of a mother training program through play and a theoretical mother training program on the mother child interaction by comparing with a control group that did not receive any training. The findings showed that the Child Parent Relationship Scale scores of mothers who participated in the Training Program in Improving Mother Child Relationship through Play changed in the positive direction meaningfully. Content analysis was employed to analyze the post-training texts of experimental, placebo and control mothers describing their relationships with their children. According to the findings, experimental mothers used positive statements most frequently. After the Mother Training program, focus group interviews were held with the experimental group mothers to ask them questions to evaluate the training program. In the 
interviews, all mothers mentioned positive projections of play based training on themselves and an increase in their awareness.

Discussion and Conclusions: In sum, this study was the first in Turkey to implement a Filial Therapy based mother training program, and it found meaningful and permanent effects which might change the mother child interaction positively. These findings contribute to the literature by corroborating the results of previous research. As the study aimed to design a mother training program based on Filial Therapy, it was implemented on a small group of volunteers; therefore, in the future it should be implemented in larger groups and different contexts. 


\title{
Anne Çocuk İlişkisini Oyunla Geliş̧irme Eğitim Programının Etkililiği
}

\author{
Ege AKGÜN** Binnur YEŞILYYPRAK ${ }^{* * *}$
}

ÖZ. Bu araştırmanın amacı Anne Çocuk İlişkisini Oyunla Geliştirme Eğitim Programının Etkililiğinin 4-5 yaş arasında çocuğu olan annelerin çocukları ile ilişki düzeyi üzerindeki etkisini incelemektir. Bu çalışma deney, plasebo ve kontrol gruplu ön-test, son-test ve izleme modeline dayalı deneysel bir çalışmadır. Araştırma, Ankara ilinde, üst sosyo ekonomik düzeydeki gönüllü annelerin katılımı ile gerçekleşmiştir. Araştırmada 10 anne deney, sekiz anne plasebo ve dokuz anne kontrol grubunda yer almıştır. Araştırmada veriler Çocuk Anababa İlişki Ölçeği, Annelerin çocukları ile ilişkilerini anlattıkları kompozisyonlar ve odak grup görüşme kayıtlarından elde edilmiştir. Elde edilen veriler Kruskall Wallis H, Mann Whitney U ve Wilcoxon Testi ile analiz edilmiştir. Deney grubundaki anneler, plasebo ve kontrol grupları ile karşılaştırıldığında deney grubundaki annelerin çocukları ile ilişkisindeki gelişme anlamlı bulunmuştur.

Anahtar Sözcükler: Anne çocuk ilişkisi, anne eğitimi, okul öncesi

\footnotetext{
* Bu çalışma “Anne Çocuk İlişkisini Oyunla Geliştirme Eğitiminin Anne Çocuk Etkileşim Düzeyine Etkisi” adlı Doktora tez çalışmasının bir bölümünden özetlenerek hazırlanmıştır. ${ }^{* *}$ Dr. Ankara Üniversitesi, Eğitim Bilimleri Fakültesi. Tel: 03123633350 /5106.

E-posta: eakgun@education.ankara.edu.tr

** Prof. Dr. Ankara Üniversitesi, Eğitim Bilimleri Fakültesi. Tel: 031236333 50/3101.

E-posta: Binnur.Yesilyaprak@education.ankara.edu.tr
} 


\section{GİRIŞ̧}

Çocuğun sağlıkl1 gelişim göstermesinde belirleyici etkileri olan anne babaların, çocuk gelişimi ve eğitimi konularında bilgilenmeleri, bilinçlenmeleri ve öğrendiklerini davranışa dönüştürebilmeleri için belli bir program çerçevesinde eğitim almaları önemlidir.

Anne baba eğitiminin temel amacı, çocuklarının sağlıklı fiziksel, zihinsel, sosyal ve duygusal gelişimi için anne ve babalarının özgüvenini güçlendirecek ve anne babalık becerilerini geliştirecek şekilde anne babalara rehberlik etmektir. Uygulanmakta olan programların bir kısmı doğrudan çocuğa ya da yakın çevresine, bir kısmı ise hem çocuğa hem anne babaya hizmet götürmeyi amaçlamaktadır (Arkan ve Üstün, 2009).

Anne baba eğitim programlarınının anne babaların davranışlarında kalıcı değişiklikler sağlayabilmesi için bu eğitimlere anne baba ve aynı anda çocuğun da katılması ve bu eğitimlerin içeriğinde bilgilendirme, yöntem öğretme, evde uygulama çalışmalarının olması önem taşımaktadır. $\mathrm{Bu}$ çalışmada, uygulanan anne eğitim programı hazırlanırken Filial Terapi yaklaşımından yararlanılmıştır. Bu yaklaşım anne ve çocuğun, oyun terapi becerileri doğrultusunda oyun oynamasına dayanır ve ailelerin özel koşullar gerektiren terapötik rolü üstlenmeyi öğrenme becerisini temel alır (Johnson, Bruhn, Winek, Krepps ve Wiley, 1999; Landreth ve Bratton, 2006; VanFleet, 2005; Watts ve Broaddus, 2002).

Garry Landreth (1991) Filial Terapiyi, ailelerin kendi çocukları ile çocuğun yönettiği, oyundaki tüm kararları çocuğun verdiği sembolik oyun olarak tanımlanan çocuk merkezli oyun oynamaları için koşulsuz kabul, etkin dinleme, sınır koyma, yapılandırma, çocuğun kendisini yönetmesine izin verme gibi danışma becerileri doğrultusunda eğitim aldıkları tek yaklaşım olarak tanımlamaktadır. Aileler temel danışma becerilerini öğrenirler ve bu becerileri evde çocukları ile oynadıkları oyun oturumlarında kullanırlar, kullandıkları bu oyun becerileri üzerine geribildirim alırlar. Aileler ayrıca yargılamamayı, anlamayı ve kabul etmeyi öğrenirler. Öğrendikleri bu becerileri gerçek yaşamlarına aktarmaları sayesinde anne çocuk ilişkisinin olumlu yönde değişme gösterdiği görülmektedir (Watts ve Broaddus, 2002).

VanFleet (2005) Filial Terapinin amaçlarını, çocuk yetiştirme ile ilgili problemlerin kaynağında çözümü; problemler ile daha iyi baş edebilme ve problem çözme becerisinin ve aile içi iletişimin artması, böylece anne babaların ileride karşılaşabilecekleri problemleri bağımsız ve başarılı bir biçimde çözmesi olarak belirtmiştir. Filial Terapinin aile eğitiminde kullanılması başarılı sonuçlar göstermektedir. $\mathrm{Bu}$ eğitimin kapsamında 
kazanılan etkin dinleme, çocuğun kendini yönetmesine izin verme, çocuğun duygusal ifadelerine ve davranışlarına katılım, çocuğu kabul ve empati kurma becerilerinde olumlu gelişim uzun süre devam etmektedir (VanFleet, 2005). Filial Terapi çalışmaları, anne babaların çocuklarının gereksinimlerine yönelik farkındalık düzeyinde, empatik davranışlarında, çocuklarına gösterdikleri terapötik tepkilerinde, yansıtıcı ifadelerinde, çocuğun duygu ve davranışlarını kabul düzeyinde, problem çözme becerisinde artış, ailelerin çocukları ile ilişkilerinde bağlılık, samimiyet ve iletişim boyutlarında anlamlı düzeyde gelişim ve stres düzeyinde azalma sağlamıştır (Landreth ve Lobaugh, 1998; Rennie ve Landreth, 2000). Çocukların özellikle davranış problemlerinde azalma ve çocuğun ailesi ile oyun davranışlarında artış anlamlı bulunmuştur (VanFleet, 2005).

Araştırmalara göre, Filial Terapi uygulamalarının farklı problem durumlarinda (Beckloff, 1997, Bratton ve Landreth, 1995; Costas ve Landreth, 1999; Glazer-Waldman, Zimmerman, Haris ve Landreth, 1997; Johnson ve diğ., 1999; Kale ve Landreth, 2000; Landreth ve Lobaugh, 1998; Ryan ve Madsen, 2007; Smith, 2000; Tew, Landreth, Joiner ve Solt, 2002) ve farklı kültürlerde (Chau ve Landreth,1997; Edwards, Ladner ve White 2007; Foley, Higdon ve White,2006; Grskovic ve Goetze, 2008; Jang, 2000; Kidron, 2004; Lee, 2002; Solis, Meyers ve Varjas, 2004; Yuen, Landreth ve Baggerly, 2002) oldukça etkili sonuçları görülmektedir. Farklı değişkenler ve farklı kültürlerde yapılan bu uygulamalı çalışmalar Filial Terapinin etkililiğini ortaya koymaktadır. Gerekli düzenlemeler ve uyarlamalar ile eğitim tüm dünyada farklı kültür ve etnik geçmişe sahip ailelerin oluşturduğu gruplarla uygulanabilir. Çünkü çocuk oyunları evrenseldir, fırsat verildiğinde çocuklar yaşamlarını sürdürdükleri kültürel çevreleri içinde oyun oynarlar. Programın içeriğinde de çocuklar kendi kültürel bağlamları içinde yönlendirici olmayan sembolik oyun oynamaktadırlar. Çocuğun oyun temalarını anlamada aile önemli rol oynar ve ailenin oynadığı bu rol kültürel kaynaklı yanlış anlama olasılığını azaltmaktadır. Eğitimci ailede açıklığı, empatiyi geliştirmeye, aile ile ilişkide samimi olmaya, aileleri serbestçe konuşmaları için cesaretlendirmeye gayret eder, bu etkileşim biçimi tüm ailelere uygulanabilir (VanFleet ve Guerney, 2003; VanFleet, 2005).

Çocuğun sağlıklı gelişim göstermesi, toplumda sağlıklı bir birey olarak yer alması için anne babaları ile kurduğu yakın ilişki önemlidir. Türkiye'de anne baba eğitiminin çocuğun gelişimine etkisini araştıran çok sayıda araştırma bulgusuna rastlanmaktadır (Akkök ve Sucuoğlu,1988; Aydoğmuş ve diğ. 2001; Baç-Karaaslan ve Bal, 2006; Erkan ve Durmuşoğlu, 2007; Kağıtçıbaşı, Bekman, Özkök ve Kuşcul, 1995; Kaya, 1994; Kimmet, 2004; Ömeroğlu, Can-Yaşar, 2002; Ömeroğlu, Kurtulmuş ve Yayla, 2006). Ancak 
eğitim programı kapsamında anne çocuğun iletişim kurmasının, oyun oynamasının sağlandığı az sayıda araştırma bulgusuna rastlanmaktadır. $\mathrm{Bu}$ çalışmalarda eğitim programlarında yer alan anne çocuk oyunlarının bilişsel gelişimi destekleyen, yaratıcı ya da yapılandırılmış oyunlar olduğu görülmüştür (Sevinç ve Evirgen, 2004; Turan, Ersoy, Şahin ve Turla, 1996; Turan, Aksoy ve Turla, 1997). Annelerin çocukları ile çocuk merkezli oyun oynayarak eğitim aldıkları Filial Terapiye dayanan bir çalışmaya Türkiye'de rastlanmamıştır. Oyunun çocuğun yaşamındaki anlamı ve okul öncesi çağda çocukla sağlıklı etkileşimin oyun yolu ile olduğu dikkate alındığında anne çocuk ilişkisini geliştirme amacını taşıyan bir eğitim programında anne ve çocuğun çocuk merkezli oyun oynamasının önemi büyüktür. Oyunun bir program dahilinde anne çocuk ilişkisindeki etkisinin belirlenmesi ile benzer eğitim programlarında oyunun yer alması açısından önem taşımaktadır.

\section{Araştırmanın Amacı}

4-5 yaşları arasında çocuğa sahip olan üst sosyo ekonomik düzeydeki annelere verilen “Anne çocuk ilişkisini oyunla geliştirme eğitimi” nin anne çocuk ilişki düzeyi üzerindeki etkisini incelemektir.

\section{Sinırlılık}

Araştırmanın sınırlılığı üst sosyo ekonomik düzeydeki az sayıda anne ile yürütülmüş olmasıdır.

\section{YÖNTEM}

\section{Çalışma Grubu}

Araştırmanın çalışma grubunu, 4-5 yaş arası çocuğu olan üst sosyo ekonomik düzeydeki gönüllü anneler oluşturmaktadır. Araştırma grubundaki annelere ulaşmak için anne çocuk ilişkisine odaklanan bir eğitim düzenlendiğinin anlatıldığı bir davet mektubu hazırlanmıştır. Ankara'da yer alan üst sosyo ekonomik düzey ailelerin çocuklarının devam ettiği okul öncesi eğitim kurumlarının yöneticileri ile görüşülerek araştırmanın amacı anlatılmıştır. Annelere davet mektubu göndermeyi kabul eden altı okul öncesi eğitim kurumundaki yönetici ve öğretmenlerin yardımı ile hazırlanan davet mektubu 300 anneye ulaştırılmıştır. Gönüllü olarak davet mektubuna yanıt veren ve çocuğu ile ilişkisini geliştirmek amacıyla eğitim programına katılmak isteyen 32 anne deney, plasebo ve kontrol gruplarına atanmıştır. Oyuna dayalı eğitime katılan deney grubundaki iki anne ve plasebo grubundan üç anne eğitime düzenli olarak devam etmediği için verileri araştırmaya dahil edilmemiştir. Araştırmada tüm oturumlara eksiksiz olarak katılan 27 annenin verileri kullanılmıştır. Buna göre 10 anne deney (\% 37.3), sekiz anne Plasebo (\%29.4) ve dokuz anne kontrol (\%33.3) grubunda yer 
almıştır. Annelerin demografik bilgileri deney, plasebo ve kontrol gruplarına göre Tablo 1 de gösterilmiştir.

Tablo 1. Gruplara göre annelere ait demografik bilgiler

\begin{tabular}{|c|c|c|c|c|c|c|c|c|c|}
\hline \multirow{2}{*}{$\begin{array}{l}\text { Kişisel } \\
\text { Bilgiler }\end{array}$} & & \multicolumn{2}{|c|}{ Deney } & \multicolumn{2}{|c|}{ Plasebo } & \multicolumn{2}{|c|}{ Kontrol } & \multicolumn{2}{|c|}{ Toplam } \\
\hline & & $\mathrm{n}$ & $\%$ & & $\%$ & $\mathrm{n}$ & $\%$ & $\mathrm{n}$ & $\%$ \\
\hline \multirow[t]{3}{*}{ Yaş } & $36-40$ & 2 & 20 & 2 & 25 & 5 & 5.5 & 9 & 33.3 \\
\hline & $31-35$ & 6 & 70 & & 62.7 & 4 & 44.5 & 15 & 55.5 \\
\hline & $25-30$ & 2 & 10 & 1 & 12.3 & - & - & 3 & 11.2 \\
\hline Öğrenim & Universite & 6 & 60 & 4 & 50 & 8 & 88.9 & 18 & 66.7 \\
\hline Durumu & Lise & 4 & 40 & 4 & 50 & 1 & 11.1 & 9 & 33.3 \\
\hline \multirow[t]{2}{*}{ Meslek } & Profesyonel & 7 & 70 & 6 & 75 & 8 & 88.9 & 21 & 77.7 \\
\hline & Ev hanımı & 3 & 30 & 2 & 25 & 1 & 11.1 & 6 & 22.3 \\
\hline Çocuk & 1 & 7 & 70 & 4 & 50 & 3 & 33.4 & 14 & 51.8 \\
\hline \multirow[t]{2}{*}{ Say1s1 } & 2 & 2 & 20 & 4 & 50 & 5 & 55.5 & 11 & 40.8 \\
\hline & 3 & 1 & 10 & - & - & 1 & 11.1 & 2 & 7.4 \\
\hline Çalışma & Evet & 5 & 50 & 4 & 50 & 7 & 77.8 & 16 & 59.2 \\
\hline Durumu & Hayır & 5 & 50 & 4 & 50 & 2 & 22.2 & 11 & 40.8 \\
\hline Toplam & & 10 & 100 & 8 & 100 & 9 & 100 & 27 & 100 \\
\hline
\end{tabular}

Tablo 1'e göre annelerin ağırlıklı olarak 30-35 yaş grubunda (\%55.5), bir çocuğa sahip (\%51.8), üniversite mezunu (\%66.7), profesyonel meslek sahibi (Mimar, Doktor, Öğretmen vb.) (\%59.2) ve çalışan anne (\%59.2) olduğu görülmektedir.

Araştırmaya annesi ile birlikte toplam 27 çocuk dahil olmuştur. Çocukların \%55,5'i 4 yaş ve $\% 44,5$ 'i 5 yaş grubundadır. Çocukların $\% 55,5$ 'i erkek ve \% 44,5'i kız olduğu görülmektedir.

\section{Eğitim Programının Hazırlanması ve Uygulanması}

Deney grubuna uygulanacak programın temelini Filial Terapi yaklaşımı oluşturmuştur. Programın hazırlanma aşamasında araştırmacı kendi gelişimi amacıyla Oyun Terapisi ve Filial Terapi eğitimlerine katılmıştır. Program geliştirilirken daha önceki çalışmalar incelenmiş ve bu yaklaşıma dayalı olarak uygulanan programlar temel alınmıştır (Bratton, Landreth, Kellam ve Blackard, 2006; Landreth ve Bratton, 2006; VanFleet ve Guerney, 2003; VanFleet, 1999, 2000, 2005). Programda oyun becerilerinin öğrenilmeye 
başlanmasından önce annelere annelik becerileri ve etkileyen bilişsel etmenler, çocuğun ihtiyaçları konularında bilinç kazandırmak amacı ile oturumlar planlanmıştır (Beck, 2001; Gordon, 2003; Kağıtçıbaşı, Bekman ve Sunar, 1993). Program içeriği, Çocuk Gelişimi ve Eğitimi ve Psikolojik Danışma ve Rehberlik alanından yedi akademisyen tarafından incelenmiş ve onların öneri ve görüşleri doğrultusunda programda değişiklikler yapılarak düzenlenmiştir.

Hazırlanan program deney grubuna, haftada 1 gün 90 dakika olmak üzere uygulanmıştır. Bu süreçte anneler, yedi hafta bilgilendirme ve beceri kazandırmaya dayalı eğitim almış ve izleyen beş hafta boyunca aldıkları eğitim doğrultusunda kendi evlerinde çocukları ile haftada 1 kez 30 dakika "çocuk merkezli oyun" oynamışlardır. Eşzamanlı olarak devam eden grup oturumlarında annelerin oyun yaşantılarını paylaşımları ve geribildirimler ile eğitim toplam 12 hafta sürmüştür. Programda kullanılan eğitsel yöntemler; rol oynama, soru-yanıt, kuramsal bilgiye dayalı sunuş yöntemi, model olma, hazırlık oyunları, örnek uygulamaları izleme (VanFleet, 1999) ve grup tartışmasıdır.

Eğitim programının oturumlarında yer alan konular şu şekildedir:

1. Oturum: Tanışma, eğitim programı ile ilgili bilgi verme ve kuralların kararlaştırılması.

2. Oturum: Annelik becerilerine güvenme. Annelik rolü ve davranış biçimini etkileyen bilişsel etmenler

3. Oturum: Çocuğun ihtiyaçları ve bunları karşılamada anne babanın yapmas1 gerekenler

4. Oturum: Çocuğun gelişiminde oyunun önemi, çocuk merkezli sembolik oyun becerileri

5. Oturum: Yapılandırma becerileri

6. Oturum: Empatik dinleme becerileri

7. Oturum: Sinır koyma becerileri

8.9.10.11.12. Oturumlar: Bu oturumlar iki bölümden oluşmaktadır: Evde oyun oturumları, Anne çocuk oyun oturumları ile ilgili geribildirimlerin verilmesi ve tartı̧̧ma.

Plasebo grubu için hazırlanan programda, deney grubu için hazırlanan eğitim programı temel alınmıştır. Programda yer alan beceri öğrenmeye dayalı uygulamalar çıkarılmış ve anne baba tutumları; olumlu-olumsuz disiplin yolları eklenerek yedi oturumluk eğitim programı oluşturulmuştur. 
Plasebo grubu yedi hafta boyunca haftada 1 kez 90 dakika olmak üzere eğitim almıştır. Plasebo grubuna uygulanan eğitim, deney grubuna verilen teorik eğitim ile süresinin aynı olması amaciyla yedi oturum olarak planlanmıştır.

Kontrol grubundaki annelere deney süresince hiçbir uygulama yapılmamış; izleme testlerinin uygulanmasının ardından iki saat süren "Anne çocuk ilişkisi ve oyun" konulu eğitim çalışması gerçekleştirilmiştir.

Deney, plasebo ve kontrol grubundaki annelere ön- son ve izleme testi olarak Çocuk Anababa İlişki Ölçeği uygulanmıştır. Son testle birlikte, tüm anneler çocukları ile ilişkilerini anlatan yazı yazmışlardır. Deney grubundaki annelerin eğitim programını değerlendirdikleri odak grup görüşmesi video kamera ile kaydedilmiştir. Kontrol grubundaki annelerin öntest ve sontest uygulamas1 arasındaki süre yedi hafta; son test ve izleme testi arasındaki süre üç ay olarak verilmiştir.

\section{Verilerin Toplanması}

\section{Veri Toplama Araçları}

Araştırmada, nicel ve nitel veriler eş zamanlı olarak toplanmıştır. Bu yöntem, bulguların birbirlerinin destekleyip desteklemediğine bakılmasını ve böylece araştırma yönteminde zenginleşmeyi sağlayan bir uygulamadır. Literatürde zenginleştirilmiş desen (tringulation) olarak adlandırılan bu uygulama ideal görülen bir yöntemdir (Büyüköztürk, Çakmak, Akgün, Karadeniz ve Demirel, 2008).

\section{Çocuk Anababa İlişki Ölçeği (ÇAïÖ)- Child Parent Relationship Scale, CPRS (Pianta, 1992)}

Araştırmacı tarafından Türkçe'ye uyarlanan ölçeğin orjinali Pianta (1992) tarafından anne çocuk ilişkisini anlamak ve değerlendirmek amacı ile geliştirilmiştir. Ölçeğin orjinali 30 maddeden oluşmakta ve çatışma, bağlanma ve olumlu ilişki olmak üzere üç alt boyutu bulunmaktadır. Ölçek 5'li Likert tipi bir ölçek olup (1) Kesinlikle uygun değil ile (5) Kesinlikle çok uygun arasında yanıtlanmaktadır. Ölçekte olumlu ve olumsuz ifadeler vardır ve olumsuz ifadeler tersine çevrilerek puanlanmaktadır. Ölçeğin orijinal normları 4,5-5,5 yaşlarında çocukları olan 714 anne babadan elde edilmiştir. Sonuçlara göre her bir alt boyut için Cronbach Alfa katsayıları sırasıyla Çatışma .83, Olumlu ilişki .72 ve Bağlanma .50 dir (Pianta,1992).

Ölçeğin Türkçe'ye uyarlama çalışmalarında ilk olarak ölçek iyi derecede İngilizce bilen dört alan uzmanı tarafından ayrı ayrı Türkçeye çevrilmiştir. Yapılan düzeltmelerden sonra ölçek maddeleri bir uzman 
tarafından Türkçe' den İngilizce' ye ters çeviri yapılmıştır. Anlamda bir farklı1ık olmadığı görüldükten sonra İngilizce bilgisi yeterli iki alan uzmanı tarafindan ölçeğin İngilizce ve Türkçe formu karşılaştırılarak düzeltmeler yapılmıştır. Çeviri işlemlerinden sonra ölçeğin Türkçe formunun kapsam geçerliği için alanda çalışan 10 uzmanın görüşlerine başvurulmuştur. Uzmanlar her bir maddenin anne çocuk ilişkisini ölçmede yeterli olup olmadığını 5'li Likert tipi ölçek düzeyinde değerlendirmiş̧lerdir. (1) Hiç yeterli değil anlamına gelirken (5) çok yeterli anlamındadır. Uzmanların her bir madde için verdikleri puanların ortalaması alınmış ve elde edilen sonuçlara göre tüm maddelerin ortalamasının 3 ve üstü olduğu görülmüş ve ölçekte yer alan tüm maddelerin anne çocuk ilişkisini ölçmede yeterli olduğuna karar verilmiştir. Ölçek maddeleri üzerinde uzmanların görüşleri yönünde düzeltmeler yapılarak, ölçeğin pilot uygulaması 5-6 yaş grubu çocuğu olan 20 anne ile yapılmıştır. Annelerden ölçeği doldururken anlamadıkları, uygun bulmadıkları maddeleri belirtmeleri istenmiştir. Bir maddede ifade yanlışlığından kaynaklanan bir düzeltme yapılmıştır.

Daha sonra ölçek 183 anneye uygulanmış ve elde edilen verilere ölçeğin yapı geçerliğini belirlemek amacı ile faktör analizi yapılmıştır. Ölçek çatışma ve olumlu ilişki olmak üzere iki faktörlüdür. Birinci faktörde yer alan maddelerin faktör yük değeri .532 ile .703 ve ikinci faktörde yer alan maddelerin ise $.523-.768$ arasındadır. Önemli olarak belirlenen faktörlerden birincisi ölçeğe ilişkin toplam varyansın \%29'unu; ikincisi \%19'unu açıklamaktadır. İki faktörün açıkladıkları toplam varyans \%48dir. Ölçeğin test tekrar test güvenirlik katsayısı Çatışma alt boyutu için $.97 \quad(\mathrm{p}<.01)$ olumlu ilişki boyutu alt boyutu için $.87(\mathrm{p}<.01)$ toplam puan için .95 $(\mathrm{p}<.01)$ olarak bulunmuştur. Ölçeğin iç tutarlık katsayısı (Cronbach Alfa) .70, Çatışma boyutu alt ölçeği için .85; Olumlu boyut alt ölçeği için .74 bulunmuştur. Ölçekten yüksek puan alma olumsuz ilişkiyi, düşük puan alma olumlu ilişkiyi göstermektedir. Toplam puan en yüksek 75 (en olumsuz) ve en düşük 15 (en olumlu) arasındadır.

\section{Annelerin İlişki Tanımlamaları}

Eğitimin sonunda annelerin yazdıkları çocukları ile ilişkilerini tanımlayan yazılardır. Annelerin çocukları ile ilişkilerini anlattıkları yazılar içerik analizi yöntemlerinden kategorisel analiz değerlendirilmiştir.

\section{Odak Grup Görüşmesi}

Eğitimin ardından deney grubundaki annelerin odak grup görüşmesinde eğitim programını değerlendirdikleri video kamera kayıtlarıdır. Annelerin eğitim programını değerlendirdikleri odak grup görüşmesi kayıtları betimsel 
analiz tekniği ile yorumlanmıştır. Buna göre veriler belirlenen temalara göre özetlenmiş ve yorumlanmıştır.

\section{Bilgi Formu}

Annelerin demografik bilgilerini elde etmek amacı ile geliştirilen formdur. Deney, plasebo ve kontrol gruplarının bazı değişkenler açısından eşitlenmesi amacıyla bu formdan yararlanılmıştır.

\section{Verilerin Analizi}

Araştırmada elde edilen veriler aşağıdaki istatistiksel tekniklerle analiz edilmiştir. Eğitim programının araştırmaya katılan annelerin çocukları ile ilişkisi üzerindeki etkisini saptamak amacıyla araştırmada deney ve kontrol gruplarını oluşturan annelerin sayısının az olması nedeni ile Parametrik olmayan istatistiksel yöntemler kullanılmıştır. Gruplar arasındaki farkın anlamlılığ 1 Kruskall Wallis $H$ ve Mann Whitney $U$ Testi ve ölçümler arasındaki farkın anlamlılı̆̆ Wilcoxon Testi kullanılarak incelenmiştir.

Verilerin çözümlenmesinde, 05 anlamlılık düzeyi benimsenmiştir.

\section{BULGULAR}

\section{Nicel Veriler}

Ĕgitim Programının Annelerin İlişki Düzeylerine Etkisine İlişkin Bulgular

Deney, plasebo ve kontrol gruplarındaki annelerin Çocuk Anababa İlişki Ölçeğinden aldıkları öntest-sontest ve izleme testi ortalama puan ve standart sapma değerleri Tablo 2'de verilmiştir.

Tablo 2. ÇAIÖ puanlarl ortalama ve standart sapma değerleri

\begin{tabular}{lllllllllll}
\hline \multicolumn{1}{c}{ Gruplar } & \multicolumn{3}{c}{ Öntest Puan } & \multicolumn{3}{c}{ Sontest Puan } & \multicolumn{4}{c}{ İzleme Test Puan } \\
& $\mathrm{N}$ & $\overline{\mathrm{X}}$ & $\mathrm{S}$ & $\mathrm{N}$ & $\overline{\mathrm{X}}$ & $\mathrm{S}$ & $\mathrm{N}$ & $\overline{\mathrm{X}}$ & $\mathrm{S}$ \\
\hline $\begin{array}{l}\text { A-Oyuna dayalı } \\
\text { eğitim (Deney) }\end{array}$ & 10 & 33.10 & 9.38 & 10 & 28.00 & 8.73 & 10 & 27.70 & 8.16 \\
$\begin{array}{l}\text { B-Teorik Eğitim } \\
\text { (Plasebo) }\end{array}$ & 8 & 38.12 & 7.47 & 8 & 37.50 & 6.67 & 8 & 39.37 & 6.61 \\
$\begin{array}{l}\text { C-Eğitim yok } \\
\text { (Kontrol) }\end{array}$ & 9 & 32.44 & 7.76 & 9 & 32.77 & 7.37 & 9 & 33.66 & 7.12 \\
\begin{tabular}{l} 
Toplam \\
\hline
\end{tabular} & 27 & 34.37 & 8.38 & 27 & 32.40 & 8.40 & 27 & 33.14 & 8.59 \\
\hline
\end{tabular}


ÇAİÖ Puanlarının yükselmesi ilişkide olumsuzluğu göstermektedir. Tablo 2'de görüldüğü üzere, deney grubundaki annelerin öntest ÇAİÖ ortalama puan $33.10 \mathrm{iken}$ bu değer son testte 28.00 ve izleme testinde 27.70 olmuștur. Plasebo grubundaki annelerin ortalama puanları öntest 38.12, sontest 37.50 ve izleme testinde 39.37 dir. Kontrol grubundaki annelerin ortalama puanları öntest 32.44 , son test 32.77 ve izleme testinde 33.66 'dır.

Deney, plasebo ve kontrol grubundaki annelerin ÇAïÖ puanlarında deney öncesi, sonrası ve 3 ay sonrasında anlamlı bir farklılık gösterip göstermediğine ilişkin Kruskall Wallis H Testi yapılmıştır.

Eğitim öncesinde araştırmaya katılan annelerin ÇAİÖ puanlarının gruplara göre anlamlı biçimde farklılaşmadığını göstermektedir $\left[\chi^{2}(2)=2.89\right.$, $\mathrm{p}>.05]$. Bu bulgu eğitim öncesinde grupların birbirinden farklı olmadığ 1 anlamına gelmektedir. Eğitimlerden sonra uygulanan son test puanlarına göre grupların, ÇAİÖ puanlarının Kruskall Wallis H testi sonuçları Tablo 3 'de yer almaktadir.

Tablo 3. Ĕ̌itim programı sonrasında gruplara göre ÇAİ̈ puanları Kruskall Wallis H Testi sonucu

\begin{tabular}{lcccccc}
\hline Yöntem & $\mathrm{n}$ & Sira Ort. & $\mathrm{sd}$ & $\chi^{2}$ & $\mathrm{p}$ & Anlaml Fark \\
$\begin{array}{l}\text { A-Oyuna dayalı } \\
\text { eğitim (D) }\end{array}$ & 10 & 9.30 & 2 & 7.14 & .028 & A-B \\
$\begin{array}{l}\text { B-Teorik } \\
\text { eğitim (P) }\end{array}$ & 8 & 19.31 & & & & \\
$\begin{array}{l}\text { C-Ĕ̆itim } \\
\text { yok (K) }\end{array}$ & 9 & 14.50 & & & & \\
\end{tabular}

Tablo 3'e göre araştırmaya katılan annelerin ÇAİÖ den aldıkları son test puanlarının gruplara göre anlamlı biçimde farklılaştığını göstermektedir $\left[\chi_{(2)}^{2}=7.14, \mathrm{p}<.05\right]$. Bu bulgu kullanılan yöntemlerin anne çocuk ilişkisi üzerinde farklı etkilere sahip olduğunu göstermektedir. Grupların sıra ortalamaları dikkate alındığında uygulama sonrasında en olumlu gelişimin deney grubundaki annelerde olduğu görülmektedir. Gruplar arasinda gözlenen anlamlı farkın kaynağı, Mann Whitney U Testi ile incelenmiştir. Buna göre, Eğitim sonunda deney grubu ile plasebo grubundaki annelerin çocukla ilişki düzeylerinde anlamlı farkl1lık bulunmuştur $(U=12.50, \mathrm{p}<0.05)$.

Eğitimden üç ay sonrasında uygulanan ÇAİÖ izleme testi puanlarına göre grupların Kruskall Wallis H Testi sonuçları Tablo 4'de yer almaktadır. 
Tablo 4. Eğitimden üç ay sonra gruplara göre ÇAÏÖ puanları Kruskall Wallis H Testi sonucu

\begin{tabular}{lcccccc}
\hline Yöntem & $\mathrm{n}$ & Sira Ort. & $\mathrm{sd}$ & $\chi^{2}$ & $\mathrm{p}$ & Anlaml Fark \\
\hline $\begin{array}{l}\text { A-Oyuna dayalı } \\
\text { eğitim (D) }\end{array}$ & 10 & 8.65 & 2 & 9.19 & .010 & A-B \\
$\begin{array}{l}\text { B-Teorik } \\
\text { eğitim (P) }\end{array}$ & 8 & 20.00 & & & & \\
$\begin{array}{l}\text { C-Eğitim } \\
\text { yok (K) }\end{array}$ & 9 & 14.61 & & & & \\
\hline
\end{tabular}

Tablo 4'e göre eğitimden üç ay sonra araştırmaya katılan annelerin ÇAİÖ'den aldıkları izleme testi puanlarının gruplara göre anlamlı biçimde farklılaştığını göstermektedir $\left[\chi_{(2)}^{2}=9.19, \mathrm{p}<.05\right]$. Grupların ikili birleşimleri üzerinden Mann Whitney U-testi uygulanarak gruplar arasında gözlenen anlamlı farkın kaynağı incelenmiştir. Eğitimden üç ay sonrasında deney grubundaki anneler ile plasebo grubundaki anneler arasında anlamlı farkl1lik bulunmuştur $[\mathrm{U}=9.00, \mathrm{p}<.05]$. $\mathrm{Bu}$ bulgu deney grubundaki annelerin çocukları ile ilişki düzeyleri üzerinde son testlerde çıkan anlamlı farkın üç ay sonrasında da sürdüğünü göstermektedir.

Gruplara göre annelerin öntest ve sontest ÇAİ̈ puanları arasında anlamlı bir farklılık gösterip göstermediklerine ilişkin Wilcoxon işaretli sıralar testi sonuçları Tablo 5'de verilmiştir.

Tablo 5. Gruplara göre öntest ve sontest ÇAÏÖ puanlarının Wilcoxon Işsaretli Stralar Testi sonuçlart

\begin{tabular}{lllcll}
\hline Grup & Sontest- Öntest & $\mathrm{n}$ & Sira Ortalaması & $\mathrm{z}$ & $\mathrm{p}$ \\
\hline Deney & Negatif Sıra & 9 & 6.00 & $2.70^{*}$ & .007 \\
& Pozitif sıra & 1 & 1.00 & & \\
Plasebo & Negatif Sıra & 4 & 4.13 & -.42 & .670 \\
& Pozitif sıra & 3 & 3.83 & & \\
& Eşit & 1 & & & \\
Kontrol & Negatif Sıra & 2 & 3.75 & -.631 & 1.403 \\
& Pozitif sıra & 4 & 3.38 & & \\
& Eşit & 3 & & & \\
\hline
\end{tabular}

* Pozitif siralar temeline dayalı

Tablo 5'e göre araştırmaya katılan annelerden sadece deney grubundaki annelerin ÇAİÖ den aldıkları öntest ve sontest puanları arasında anlamlı bir 
farkl11ık olduğunu göstermektedir $(\mathrm{z}=2.70, \mathrm{p}<.05)$. Fark puanlarının sıra toplamları dikkate alındığında, gözlenen bu farkın negatif sıralar yani öntest puanı lehinde olduğu görülmektedir. $\mathrm{Bu}$ sonuçlara göre düzenlenen anne çocuk ilişkisini oyunla geliştirme eğitim programının anne çocuk ilişkisini geliştirmede anlamlı bir etkisinin olduğu söylenebilir.

Gruplara göre annelerin sontest ve izleme testi ÇAİÖ puanlarında anlamlı bir farklılık gösterip göstermediklerine ilişkin Wilcoxon işaretli sıralar testi sonuçları Tablo 6'da verilmiştir.

Tablo 6. Gruplara göre sontest ve izleme testi ÇAİÖ puanlarının Wilcoxon İşaretli Siralar Testi sonuçları

\begin{tabular}{llcccc}
\hline Grup & İzleme-Sontest & $\mathrm{n}$ & Sira Ortalaması & $\mathrm{z}$ & $\mathrm{p}$ \\
\hline Deney & Negatif Sıra & 7 & 4.71 & .56 & .571 \\
& Pozitif sıra & 3 & 7.33 & & \\
Plasebo & Negatif Sıra & 2 & 3.25 & -.84 & .400 \\
& Pozitif sıra & 4 & 3.63 & & \\
& Eşit & 2 & & & \\
Kontrol & Negatif Sıra & 2 & 3.00 & -.528 & .161 \\
& Pozitif sıra & 5 & 4.40 & & \\
& Eşit & 2 & & & \\
\hline
\end{tabular}

* Pozitif siralar temeline dayalı

Tablo 6'ya göre araştırmaya katılan annelerin çocukları ile ilişki düzeylerinde son test ve izleme testi puanlarında anlamlı bir farkl1l1k gösterip göstermediklerine ilişkin yapılan Wilcoxon işaretli sıralar testi sonuçlarına göre annelerin ÇAïÖ testi puanları anlamlı biçimde farklılaşmamıştır $(\mathrm{z}=.56, \mathrm{p}>.05 ; \mathrm{z}=-.84 \mathrm{p}>.05 ; \mathrm{z}=-.528, \mathrm{p}>.05)$. Bulgular deney grubundaki annelerde sontestlerde izlenen olumlu değişikliğin eğitimden üç ay sonrasında sürdügünü göstermektedir. Bu sonuçlara göre düzenlenen oyunla anne çocuk ilişkisini geliştirme eğitim programının anne çocuk ilişkisini geliştirmedeki etkisinin kalıcılık göstereceği söylenebilir.

\section{Nitel Veriler}

\section{Annelerin İlişki Tanımlamalarına Dayalı Bulgular}

Araştırmada deney, plasebo ve kontrol grubunda yer alan annelerin, eğitimler sonrasında, çocukları ile ilişkilerini tanımladıkları komposizyonlara içerik analizi yöntemlerinden kategorisel analiz tekniği uygulanmıştır. Annelerin ilişkilerini anlatırken kullandıkları olumlu ifadeler Tablo 7'de yer almaktadır. 
Tablo 7. Annelerin çocukları ile ilişkilerini tanımlarken kullandıkları olumlu ifadeler

\begin{tabular}{lccc}
\hline Olumlu İfade & \multicolumn{3}{c}{ İfadeyi Kullanan Anne Sayıs1 } \\
& Deney & Plasebo & Kontrol \\
\hline Yaşantı paylaşma & 4 & - & 4 \\
Duygu paylaşma & 5 & 3 & 4 \\
Sevgiyi ifade etme & 5 & 3 & 4 \\
İyi/sağliklı/ olumlu ilişki & 6 & - & 2 \\
Kolay/ olumlu iletişim & 3 & 3 & 1 \\
Paylaşım/ Anlaşma & 7 & 3 & 1 \\
$\begin{array}{l}\text { Birlikte iyi zaman geçirme/ } \\
\text { zevk alma/keyifli/ eğlenme }\end{array}$ & & & \\
Birliktelikten mutlu olma & 9 & 6 & 3 \\
Önemli/güzel/özel/değerli davranma/ & 5 & 1 & 1 \\
hissetme/güven & 5 & & \\
Konuşma/ sohbet & 4 & - & 2 \\
İçtenlik/samimiyet/koşulsuz sevgi & 3 & - & - \\
& & & \\
\hline
\end{tabular}

Tablo 7'ye göre deney grubundaki annelerin diğer annelere göre çocukları ile ilişkilerini tanımlarken daha fazla olumlu ifadeye yer veren anne grubu olduğu görülmektedir.

Annelerin ilişkilerini tanımlarken kullandıkları olumsuz ifadeler Tablo 8 'de yer almaktadır.

Tablo 8. Annelerin çocukları ile ilişkilerini tanımlarken kullandıkları olumsuz ifadeler

Olumsuz İfade
İadeyi Kullanan Anne Sayis1
Deney

\begin{tabular}{lccc}
\hline İnatlaşma & 3 & 6 & 6 \\
Kolay Öfkelenme & - & - & 2 \\
Üzme/yıpratma/ yıldırma/ yorma/ & & & \\
bunalma/ baş edememe & - & 7 & 4 \\
İletişim kuramama, Yaşantı paylaşmama & - & 7 & 2 \\
Çatışma/ gerginlik/ çekişme/ anlaşamama & - & 7 & 2 \\
Bir taraf kazanır/ pes eder & - & 2 & -
\end{tabular}

Tablo 8'e göre tüm annelerin ilişkilerini tanımlarken kullandıkları olumsuz ifadeler içinde en fazla inatlaşma maddesini kullandıkları görülmüştür. Deney grubundaki anneler başka olumsuz ifade kullanmamışlardır. Plasebo grubundaki annelerin fazla olumsuz ifade 
kullanması bu durumun ilişkilerine yönelik farkındalıklarının artması ve araştırmacıdan aldıkları eğitim doğrultusunda problemlerini paylaşma, çözüm arama çabasından kaynaklandığı düşünülmektedir.

\section{Annelerin Programı Değerlendirmelerine İlişkin Bulgular}

Oyunla anne çocuk ilişkisini geliştirme eğitimine katılan anneler (deney grubu) ile eğitim programının tamamlanmasının ardından odak grup görüşmesi yapılmıştır. Anneler sorulan sorular doğrultusunda eğitim programını değerlendirmişlerdir. Programın amacına ulaşıp ulaşmadığının değerlendirilmesi annelerin kendilerindeki değişimi anlatmaları yoluyla gerçekleştirilmiştir. Bu değerlendirmeler sayısal veriler ile birlikte değerli bulguları içermektedir. Annelerin değerlendirmeleri incelenen boyutlar açısından özetlenmiştir.

\section{Programın Annelerin Davranışlarına Yönelik Farkındalık Düzeylerine Yansımaları}

Görüşmede tüm anneler oyuna dayalı eğitim almanın kendilerine yönelik olumlu yansımalarından ve farkındalıklarının arttığından söz etmişlerdir. Anneler öncelikle çocukları ile ilişkilerinde, çocuklarını yönlendirme ve sınır koymada eksik ve hatalarını fark ettiklerini, eğitim öncesinde duruma uygun yöntemi bilmediklerini, çocuklarından beklentilerinin yüksek olduğunu ve daha önce "onun dünyasına giremediklerini" fark ettiklerini ifade etmişlerdir. Eğitim sonrasında, çocukları ile daha kolay iletişim kurduklarını, daha önce çeşitli kaynaklardan çok sayıda bilgi edindiklerini, ancak uygulamaya yansıtamadıklarını anlatmışlardır. Anneler çocukları ile ilişkilerinde birçok şeyi ertelediklerini, bu ilişkiye daha fazla özen göstermeleri gerektiğini, çocuklarını bazı özelliklerini tanımadıklarını fark ettiklerini belirtmişlerdir. Daha önce oyunlarının genellikle yönlendirici ve öğretici olduğunu ve hatta gerçekten "hiç oyun oynamadıklarını" fark etmişlerdir. Anneler çocuklarına verdikleri tepkilerin sadece çocuklarının yaptıklarından kaynaklanmadığını, kendi duygusal durumları ile ilişkili olduğunu ve bu durumun çocukları ile ilişkilerini olumsuz yönde etkilediğini fark ettiklerini belirtmişlerdir.

"Aslında sadece bakış açısı ile ilgiliymiş verdiğimiz tepkiler. Yine ayn derecede yorgundum, yine ayn derecede sinirliydim. Ama N'.ye verdiğim tepkiler farklılaştı. Mevcut durum değişmedi ama tepki çok değişti. Ve dolaylsıyla da ilişkimiz değişti. Bu bir zenginlik oldu benim için. Beklentilerimi o anlamda hakikaten fazlası ile karşıladı eğitim. Başka bir kapı açtı, başka bir boyut açtı." 


\section{Programın Annelerin Çocukları İle İlişkilerine Yansımaları}

Eğitimin anne çocuk ilişkisine yansımalarını değerlendirirken, yedi anne ilişkilerinde belirgin farklılıklar olduğunu ifade etmişlerdir. Anneler çocukları ile nitelikli ve mutlu zaman geçirmeye başladıklarını ve çocuklarının olumlu yönde geribildirimler verdiğini, çocukları ile yaşadıkları problem durumlarında terapötik becerileri kullandıklarını, sınır koyduklarını ve sonuçlarından çok yararlandıklarını belirtmişlerdir.

"Uygulama aşaması, oyun aşaması inanılmaz mutlu etti beni. Oynarken D.’nin ne kadar keyif aldı̆̆ını gördüm; benimle zaman geçirmeyi ne kadar istediğini, oyunun, birlikte paylaştığımı o özel anın onun için ne kadar önemli olduğunu birebir gördüm. Ve inanılmaz derecede şaşırdım."

"Oğlumla ilişkimiz gerçekten daha iyi, sevecen, sakin, sicak oldu. Oyunun sonunda annecim seni seviyorum diye sarlld, sen benimle önceden böyle oynuyordun (somurtan palyaçoyu göstererek) şimdi gülerek oynuyorsun dedi."

\section{Programın Çocukların Davranışlarına Yansımaları}

Oyuna dayalı eğitim programına katılan tüm anneler, eğitim programını değerlendirirken çocuklarına ilişkin olumlu yansımalarından söz etmişlerdir. Çocuklarının eğitim öncesi ile kıyaslandığında beklemeyi öğrendiklerini, sınırlara çok daha kolay uyum gösterdiklerini, duygu ve isteklerini sözel olarak daha iyi ifade edebildiklerini, seçenekleri değerlendirerek kararlara daha kolay katılım sağladıklarını belirtmişlerdir.

"Kızım benimle oyun oynamak istediğini söylediğinde ona zamanın gelmediğini söyledim, ısrar ve ağlamak yok, kapının önünde oturup zamanın gelmesini beklediğinde çok şaşııdım."

"Oğlum böbrek taşı düşürüyor, sıkıntılı bir dönem, oyununda arabalarına küvette ılık duş aldırdı; geçecek iyi olacaksını, dedi. Yaşadıklarını oyun aracılığ ile ifade etmesi beni sevindirdi."

\section{Programın Yetersiz Yönleri}

Üç anne, eğitimin süresinin kısalığını ve babaların eğitim programına katılımının sağlanmamasını eğitim programının yetersiz yönü olarak ifade etmiştir. İki anne oyun oturumlarında çocuğu sözel olarak izlemenin ve yönlendirici olmamanın zorluğunu yaşadığını belirtmiştir.

"Oyunlarda çocuğu izlemede zorlandım, çocuğumda onun yaptıkların tekrarlamamdan, ona sormamdan sikıld, yapma öyle 
dediği oldu. Örneğin bana kral rolünü verdi, "ne söyleyeyim” diye sorduğumda "sen kralsın nasıl konuşacağını bana mı soruyorsun kral gibi konuş dedi."

Görüşme kayıtlarından elde edilen verilere göre eğitim programının annelerin davranışlarına yönelik farkındalıklarına, çocukları ile ilişkilerine ve çocukların davranışlarına yansımaları olumludur.

\section{TARTIŞMA ve SONUÇ}

Araştırmada, uygulamalı ve teorik anne eğitim programının anne çocuk ilişkisi üzerindeki etkileri eğitim almayan grup ile karşılaştırılarak değerlendirilmiştir. Bulgulara göre, anne çocuk ilişkisini oyunla geliştirme eğitimine katılan annelerin Çocuk Anababa İlişki Ölçeği puanlarında olumlu yönde anlamlı bir değişme olduğu ve bu değişimin araştırmadan üç ay sonrasında da devam ettiği söylenebilir. Buna göre anne çocuk ilişkisini oyunla geliştirme eğitimi ve teorik eğitime katılmanın anne çocuk ilişkisi üzerinde farklı etkilere sahip olduğu anlaşılmaktadır. Araştırmanın sonucu aynı ölçeğin kullanıldığı benzer bir çalışma ile paralellik göstermektedir (Goodwin, 2003).

Çalışmaya katılan anneler, eğitim programını değerlendirdikleri odak grup görüşmesinde oyuna dayalı eğitimin kendi davranışlarına yönelik farkındalıklarına ve çocukları ile ilişkilerine olumlu yansımalarını belirtmişlerdir. Çeşitli araştırma sonuçlarına göre anneler, filial terapiye dayalı eğitimlere katılmanın çocuklarına saygı, biricikliğini kabul, çocuklarının özgürlük ve özerklik gibi gereksinimlerini fark etme, empati kurma, çocuğu anlama, anne babalık becerisine güvenme, kural koymada kolaylık, ilişkilerinde samimiyet, farkındalık, çocuklarına duyarlılık ve kendini yeterli algılama düzeylerinde artış olduğunu ve ilişkilerinin güçlendiğini ifade etmişlerdir (Beckloff, 1997; Costas ve Landreth, 1999; Edwards, Ladner ve White, 2007; Foley, Higdon ve White, 2006; Jang, 2000; Kale ve Landreth, 2000; Sten, 2004). Bu sonuçlar araştırmanın bulgularını desteklemektedir.

Araştırmada, odak grup görüşme kayıtlarına göre, bazı anneler çocuğu izleme, çocuğun yönlendirmesine uyum sağlama ve yönlendirici olmama konularında zorluk yaşadıklarını ifade etmişlerdir. Annelerin benzer eleştirileri yapılan farklı araştırmalarda yer bulmuştur. Solis, Meyers ve Varjas (2004) araştırmalarında annelerin çocukları ile ilişkilerinde olumlu gelişim sağladıkları ancak oyun oturumlarında izin verici ve yönlendirici olmayan tarzı sürdürmekte zorlandıklarını ifade etmişlerdir. Edwars, Ladner ve White (2007) araştırmasında anneler tarafindan izleme yapma ve sınır koymada problem ifade edilmiştir. 
Çalışmanın bulgularına göre aldıkları eğitim doğrultusunda anne çocuğun yönlendirici olmayan oyun oynamalarının ilişkilerini desteklediği nicel ve nitel veriler ile kanıtlanmıştır. Anneler oyun ortamında kullandıkları becerileri gerçek yaşamlarında kullanmaya devam ettiklerinde ilișkileri gelişme gösterecektir. $\mathrm{Bu}$ sonuç farklı araştırma bulguları ile tutarlılık göstermektedir. Brown, Gorton ve Wolery (1988) nitelikli etkileşim düzeyinin artırılması ile anne ve çocuk arasındaki ilişkinin doyumlu hale gelebileceği ve bunun da ilişkinin sürdürülmesinde çok önemli bir etken olduğunu ifade etmektedirler. Annelerin çocuk merkezli oyun becerilerini öğrenmeleri, çocuklarla etkileşimin niteliğinin artmasına ve yeni becerilerin kazanılmasına olanak sağlamıştır (Landreth ve Bratton, 2006).

Araştırmada nitel ve nicel veriler birbirini destekler niteliktedir. Benzer şekilde, nitel ve nicel verilerin birlikte kullanıldığı araştırma bulguları, çalışmanın bulguları ile örtüşmektedir. Ryan ve Madsen (2007) araştırmasında, eğitimde yer alan beceriler anne babalar tarafından başarı ile uygulanmıştır. Ailedeki tutum, aile bireyleri arasındaki ilişki ve çocukların problem davranışları üzerindeki olumlu değişikliklerin kalıcı olduğu bulunmuştur. Araştırma bulguları ile örtüşen sonuçların yanı sıra bazı araştırma bulguları kısmen tutarlı sonuçlar ortaya koymaktadır. Glover ve Landreth'in (2000) çalışmasında annelerin istendik oyun davranışlarında olumlu yönde değişme olmuş ancak anne babaların çocuklarını kabul düzeyinde anlamlı artış gerçekleşmemiştir.

Türkiye'de yapılan benzer bir çalışma ile araştırma bulguları tutarlıdır. $\mathrm{Bu}$ çalışmada okul destekli anne eğitim programına katılarak çocukları ile ilişkilerinde olumlu tutum geliştiren annelerin çocukları ile daha çok etkileşim kurdukları, onları dinledikleri, çocukları ile daha çok konuştukları, öyküler okudukları, oyunlar oynadıkları, olumlu disiplin yollarını benimsedikleri, kendilerini daha olumlu algıladıkları bulunmuştur (Sevinç ve Evirgen, 2004 ).

Oyuna dayalı anne çocuk eğitiminde aileler yargılamadan, anlama ve kabule dayalı çevre yaratmayı ve anne çocuk ilişkisini artırmayı öğrenmekte, böylece anne ve çocuğun kişisel gelişme ve değişimi kolaylaşmaktadır (Watts ve Broaddus, 2002).

Sonuç olarak, bu çalışmada Türkiye'de ilk kez Filial Terapi'yi temel alarak bir anne eğitim programı uygulanmış ve anne çocuk ilişkisinin olumlu yönde değiştirdiği ve bu olumlu değişimin eğitimden üç ay sonra devam ettiği saptanmıştır. Bu bulgunun farklı kültürlerde yapılan çalışmalarda elde edilen sonuçlar ile örtüşerek alanyazına katkı sağladığı düşünülmektedir. 
Araştırmada elde edilen bulgular 1şığında aşağıdakileri önermek mümkündür:

Verilen eğitimin uzun süreli kalıcıllğının ölçülmesi amacı ile eğitimden 1 yıl sonrası için izleme çalışmaları yapılabilir. Çocuklar anne ve babasından etkilenerek büyüdükleri için; aile içi etkileşimin önemi ve anne baba ile kurulan olumlu ilişkinin önemi dikkate alındığında oyuna dayalı anne çocuk eğitim programına anne ve babaların birlikte katılacakları araştırma desenleri oluşturulabilir. Orta ve alt sosyo ekonomik düzeydeki anneler için eğitim programı uygulanarak etkisini inceleyen araştırmalar yapılabilir. Bu çalışma Filal Terapiye dayalı anne eğitim programının hazırlanması amacını taşıdığ 1 için gönüllü küçük bir gruba uygulanmıştır bu nedenle farklı problem durumlarında ve daha büyük gruplarla uygulanması önerilebilir.

\section{KAYNAKLAR}

Akkök, F. ve Sucuoğlu, B. (1988). Aile Rehberliğinin Yuvaya Yeni Başlayan Çocukların Sosyal Becerilerinin Gelişimlerine Etkisi. Eğitim ve Bilim Dergisi, 12(68), 10-13.

Arkan, B. ve Üstün, B. (2009). Davranım Bozukluğu Olan Çocuklara Psikiyatrik Yaklaşımda Anne-Baba Eğitim Programları: İki Örnek Bağlamında Bir Değerlendirme. Psikiyatride Güncel Yaklaşımlar Dergisi, 1, 155-174.

Aydoğmuş, K., Batlaş, A., Batlaş, Z., Davaslıgil, Ü., Güngörmüş, O., Konuk, E., Korkmazlar, Ü., Köknel, Ö., Navaro, L., Oktay, A., Razon, N. ve Yavuzer, H. (2001). Ana Baba Okulu, İstanbul: Remzi Kitabevi.

Baç-Karaaslan, T. ve Bal, S. (2006). Çok Düşük Doğum Ağırlıkl Prematüre Bebeklerin Gelişimine Ev Merkezli Erken Eğitim Programlarının Etkisinin Incelenmesi. 1. Uluslar aras1 Okul Öncesi Eğitim Kongresi, 1,119-140. İstanbul: Ya-Pa Yayınları.

Beck, J. S. (2001). Bilişsel Terapi Temel İlkeler ve Ötesi. (Çev. N. H. Şahin). Ankara: Türk Psikologlar Derneği Yayınları.

Beckloff, D. R. (1997). "Filial Therapy With Children With Spectrum Pervasive Development Disorders" (Doctoral Dissertation, University of North Texas, 1997). Dissertation Abstracts International, AAT 9816128.

Bratton, S. C. \& Landreth, G. (1995). Filial Therapy With Single Parents: Effects On Parental Acceptance, Empathy And Stres, International Journal of Play Therapy,(4)1, 61-80. 
Bratton, S. C., Landreth, G. L., Kellam, T. \& Blackard, S. R. (2006). Child Parent Relationship Therapy (CPRT) Treatment Manual A 10 Session Filial Therapy Model for Training Parents. New York: Routledge Taylor \& Francis Group.

Brown-Gorton, R. \& Wolery, M. (1988). Teaching Mothers To İmitate Their Handicapped Children: Effects On Maternal Mands. The Journal of Special Education, 22 (1) 97-107.

Büyüköztürk, Ş., Çakmak, E. K., Akgün, Ö. E., Karadeniz, Ş. ve Demirel, F. (2008). Bilimsel Araştırma Yöntemleri. Ankara: Pegem Akademi.

Chau, I. Y. \& Landreth, G. L. (1997). Filial Therapy With Chinese Parents: Effects On Parental Empathic İnteractions, Parental Acceptance Of Child And Parental Stress. International Journal of Play Therapy, 6(2), 75-92.

Costas, M., \& Landreth, G. (1999). Filial Therapy With Nonoffending Parents Of Children Who Have Been Sexually Abused. International Journal of Play Therapy, 8(1), 43-66.

Edwards, N. A., Ladner, J. \& White, J., (2007). Perceived Effectiveness Of Filial Therapy For A Jamaican Mother: A Qualitatative Case Study. International Journal of Play Therapy, 16 (1),1555-6824.

Erkan, S. ve Durmuşoğlu, M.C. (2007). Anne Ĕgitim Programının Annenin Çocuk Yetiştirme Tutumlarına Etkisinin Incelenmesi, Avrupa Birliği Sürecinde Okul Öncesi Eğitimin Geleceği Sempozyumu, 1, 349360.İstanbul: Ya-Pa A.Ş.

Foley, Y. C., Higdon, L. \& White, J. F., (2006). A Qualitative Study of Filial Therapy: Parents' Voices. International Journal of Play Therapy, 15(1),1555-6824.

Glazer-Waldman, H., Zimmerman, J., Landreth, G., \& Norton, D. (1992). Filial Therapy: An İntervention For Parents Of Children With Chronic İlness. International Journal of Play Therapy, 1(1), 31-42.

Glover, G., \& Landreth, G. (2000). Filial Therapy with Native Americans on the Flathead Reservation. International Journal of Play Therapy, 9, 5780 .

Goodwin, C. E. (2003). Filial Therapy With Court-Ordered Parents Of Maltreated Children: A Multiple Case Study. (Doctoral Dissertation, Virginia Polytechnic Institute and State University) Dissertation Abstracts International, AAT, 3095201. 
Gordon, T.(2003). Etkili Anababa Eğitimi, Uygulamalar. (Çev. E. Aksay). İstanbul: Sistem Yayınları.

Grskovic, J. A. \& Goetze, H. (2008). Short-Term Filial Therapy With German Mothers: Findings From A Controlled Study. International Journal of Play Therapy, 17( 1),1555-6824.

Harris, Z. \& Landreth, G. (1997). Filial Therapy With Incarcerated Mothers: A Five Week Model, International Journal of Play Therapy, 6(2), 5373.

Jang, M. (2000). Effectiveness Of Filial Therapy For Korean Parents. International Journal of Play Therapy, (9), 2, 21-38.

Johnson, L., Bruhn, R., Winek, J., Krepps, J. \& Wiley, K. (1999). The Use Of Child-Centered Play Therapy And Filial Therapy With Head Start Families: A Brief Report. Journal of marital and family therapy, 25(2), 169-176.

Kağıtçıbaşı, Ç., Bekman, S. ve Sunar, D. (1993). Anne Eğitim Programı Klavuzu. İstanbul: Unicef ve Boğaziçi Üniversitesi Yayını.

Kağıtçıbaşı, Ç., Bekman, S., Özkök, Ü. S. ve Kuşçul, H. (1995). Anne Destek Programı El Kitabı. İstanbul: Anne Çocuk Eğitim Vakfı Yayınları I.

Kaya, Ö. (1994). Annelere Verilen Eğitimin Çocuklarına Karşı İstenmedik Tutumlarına Etkisi, Yayınlanmamış Doktora Tezi, Gazi Üniversitesi Sosyal Bilimler Enstitüsü, Ankara.

Kale, A. L., \& Landreth, G. (2000). Filial Therapy With Parents Of Children Experiencing Learning Difficulties. International Journal of Play Therapy, 8(2), 35-56.

Kidron, M. (2004). "Filial Therapy with İsraeli Parents". (Doctoral Dissertation, University of North Texas, 2004) Dissertation Abstracts International, AAT, 3117269.

Kimmet, E. (2004). Erken Çocukluk Eğitiminde Farklı Yaklaşım Ve Uygulamalar Baba Destek Programı. OMEP Dünya Konsey Toplantıs1 Ve Konferansı Bildiri Kitabı, (Ed. G.Haktanır ve T. Güler) 1, 371379.İstanbul: YA-PA Yayınları.

Landreth, G.L. (1991). Play Therapy: The Art Of The Relationship. Muncie, IN: Accelerated Development. 
Landreth, G. L. \& Lobaugh, F. A. (1998). Filial Therapy With İncarcerated Fathers: Effects On Parental Acceptance Of Child, Parental Stress, And Child Adjustment. Journal of Counseling and Development, 76, (2), 157-165.

Landreth, G. L. \& Bratton, S. C.(2006). Child Parent Relationship Therapy (CPRT) A 10 Session Filial Therapy Model. New York: Routledge Taylor \& Francis Group.

Lee, M. (2002). "Filial Therapy With İmmigrant Korean Parents in The Untied States" (Doctoral Dissertation, University of North Texas, 2002). Dissertation Abstracts International, A 63 (09), 3115.

Ömeroğlu, E. ve Can-Yaşar, M. (2006). Aile Çocuk Eğitim Programının Aile Iç̧i Etkileşime Etkisinin İncelenmesi. 1. Uluslar arası Okul Öncesi Eğitim Kongresi, 2, 241-255. İstanbul: Ya-Pa Yayınları.

Ömeroğlu, E., Kurtulmuş, Z. ve Yayla, Ş. (2006). Aile Çocuk Eğitim Programının Aile Yapısı, İşleyişi, Ve Kaygı Düzeyine Etkisinin Incelenmesi. 1. Uluslararası Okul Öncesi Eğitim Kongresi, 1, 140-154. İstanbul: Ya-Pa Yayınları.

Pianta, R. C. (1992). Child-Parent Relationship Scale. University of Virginia. Author.

Rennie, R. \& Landreth, G. (2000). Effects Of Filial Therapy On Parent And Child Behaviours, International Journal Of Play Therapy, (9)2, 19-37.

Ryan, S. D. \& Madsen, M. D., (2007). Filial Family Play Therapy With An Adoptive Family: A Response To Preadoptive Child Maltreatment. International Journal of Play Therapy, 16( 2),1555-6824.

Sevinç, M. ve Evirgen, Ş. (2004). Küçükçekmece Okulöncesi Eğitim Merkezinde Verilen Okul Destekli Anne Eğitim Programının Anneler Üzerindeki Etkileri. OMEP Dünya Konsey Toplantısı Ve Konferans1 Bildiri Kitabı, (Ed. G.Haktanır ve T. Güler) 2, 99-120. İstanbul: YA-PA Yayınlar1.

Smith, N. R. (2000). “A Comparative Analysis Of Intensive Filial Therapy, Intensive Individual Play Therapy, And Intensive Sibling Group Play Therapy With Child Witnesses Of Domestic Violence" (Doctoral Dissertation, University of North Texas, 2000). Dissertation Abstracts International, A 62 (07), 2353. 
Solis, C. M., Meyers, J., \& Varjas, K. M. (2004). A Qualitative Case Study Of The Process And Impact Of Filial Therapy With An African American Parent. International Journal of Play Therapy, 13, 99-118.

Sten, R. L. (2004). "Adapting Filial Therapy For Families Who Have A Child With A Life-Threatening Illness". (Doctoral Dissertation University of North Texas,2004) Dissertation Abstracts International, AAT, 3145012 .

Tew, K., Landreth, G., Joiner, K. \& Solt, M. (2002). Filial Therapy with Parents of Chronically Ill Children. International Journal of Play Therapy, 11(1), 79-100.

Turan, E., Ersoy, Ö., Şahin, F. ve Turla, A., (1996). “Okul Öncesi Eğitiminin Yaygınlaştırılmasında Bir Model Önerisi: 0-4 Yaş Çocuk Gelişiminde Anne Eğitimi Projesi." III. Ulusal Eğitim Kongresi Bildiri Kitabl, Bursa.

Turan, E., Aksoy, A., Turla, A., (1997). Anne Çocuk Eğitim Programı. Okul Öncesi Eğitim Sempozyumu, Okul Öncesi Eğitimde Yeni Yaklaşımlar. (Ed. G . Haktanır). Ankara: Ankara Üniversitesi Basımevi, 84-91.

VanFleet, R. (1999). Introduction to Filial Play Therapy Video Workshop Manual. USA: Play Therapy Press.

VanFleet, R. (2000). A Parents Handbook of Filial Play Therapy Building Strong Families with Play. USA: Play Therapy Press.

VanFleet, R. \& Guerney L. (Ed.) (2003). Casebook of Filial Therapy. Pennsylvania: Play Therapy Press.

VanFleet, R. (2005). Filial Therapy: Strengthening Parent-Child Relationships Through Play. (Second Edition) USA: Professional Resource Press.

Watts, R. E. \& Broaddus. J. L. (2002). Improving Parent-Child Relationships Through Filial Therapy: An Interview with Garry Landreth. Journal of Counseling and Development: JCD. 80 (3), 372-380.

Yuen, T., Landreth, G., ve Baggerly, J. (2002). Filial Therapy With Immigrant Chinese Parents. International Journal of Play Therapy, 11(2), 63-90. 
